\title{
NON-AGENDA
}

With the view of causing an increase to take place in the mass of national wealth, or with a view to increase of the means either of subsistence or enjoyment, without some special reason, the general rule is, that nothing ought to be done or attempted by government. The motto, or watchword of government, on these occasions, ought to be - Be quiet...Whatever measures, therefore, cannot be justified as exceptions to that rule, may be considered as non-agenda on the part of government.

\section{Student Unions, Shop Stewards and Sausage Rolls}

\section{John Warhurst}

$\mathrm{O}$ n 16 March 2005 the Minister for Education, Dr Brendan Nelson, introduced into the House of Representatives the Higher Education Support Amendment (Abolition of Compulsory Up-Front Student Union Fees) Bill 2005. This is a bill to abolish what is commonly known as compulsory student unionism in Australia's universities, though its supporters prefer the term universal student unionism. Since the election of the Howard government in 1996 several previous attempts by the government to pass such legislation have been unsuccessful. But the success of the Coalition parties in winning control of the Senate, from 1 July 2005, at the October federal election means that the Senate will no longer be able to block this legislation as it has done in the past.

From a university perspective there is a strong case for the maintenance of compulsory student union (CSU) fees in Australian universities. Numerous cases have been made that relate to the necessity of maintaining various student services, ensuring the public voice of students, and preventing the adverse impact on the wider communities within which universities are located. This paper, while recognising several of the others, concentrates on the likely impact of the bill on the quality of campus community life. The provision of campus student services for use by students individually is one aspect of this life, but collective community activities are more important.

Yet it seems almost certain now that after 1 July the government will persist in introducing voluntary student unionism (VSU). If the government sticks to its guns it will be the most uncompromising form of VSU possible among several

John Warhurst is Professor of Political Science, Faculty of Arts, The Australian National University. 
possibilities. That is, it is a form that not only prevents the use of the student fee for political purposes but also prevents any general fee for services being charged.

At present full-time university students must pay a fee in the order of between approximately $\$ 100$ and $\$ 600$ per year or pro rata for part-time students. In return they are provided with membership of the student association and access to common student services, of which the most significant are food, refreshments and sporting facilities.

These organisations are not unions in the same sense as trade unions though the name probably hasn't helped their defenders. It has enabled some cheap shots from abolitionists describing university Vice-Chancellors and administrators as 'shop stewards in suits' (The Australian, 23 March 2005) They are unions only in the generic sense of a collective activity.

The campaign against the bill, led by the National Union of Students, has included a national Day of Action on 28 April. Support has come from the National Tertiary Education Union, the Australian Vice-Chancellor's Committee, and other student bodies.

Nevertheless it appears that the only hope for the defeat of the bill lies with one or more of the 39 Coalition senators breaking ranks and choosing not to support the bill in its present form. This is possible but unlikely as party discipline usually reigns supreme. Sanctions against dissidents can be severe. Nevertheless it is possible. One of the new National Party senators, Barnaby Joyce of Queensland, has already voiced his doubts about the merits of the bill and the damage it might do to student services, particularly sports facilities, at regional universities such as the University of New England in Armidale, New South Wales.

There is also a case against CSU. In addition to the principle of freedom of association, there has been abuse of the system in the past, for political and other reasons. There have been frequent political donations by student unions to leftwing causes not shared by the majority of students. There has been shoddy book keeping and preference to mates by student associations and associated clubs and societies. There have been sports unions that have sought glory in elite sport rather than the participation of as many students as possible. Most of this is well in the past, though, as universities have worked hard on reform of the system.

My own interest in student unions stems not just from more than thirty years as a university staff member at four Australian Universities, but also from my particular experience at the Australian National University (ANU). For six years, four as chair, I was a member of the University Council committee, known as the General Service Fee committee, which advised Council on the distribution of this fee among student organisations and services.

The structure and nomenclature of student organisation varies from one university to the next. At ANU the three student bodies are the Student Union (ANUSA), the Union and the Sports Union, all meant to be representing mainly undergraduate students. Individual clubs and societies, such as debating, music, arts, politics, country-of-origin and general interest are funded indirectly through ANUSA. Sometimes artistic activities organised by students in halls of residence 
and colleges are also given financial assistance. The Union provides food services, indoor recreation facilities, like pool rooms, and professional services, like dentists and optometrists. The Postgraduate and Research Students Association (PARSA) represents the growing number of postgraduate students. For various reasons, such as the fact that some postgraduates spend considerable time off campus and that some are located on parts of the campus far removed from student facilities, it was postgraduates who felt the distribution of student services was inequitable. The committee spent considerable time, too, trying to make the distribution of funds as fair and as transparent as possible. The Union was being encouraged successfully towards independence from any student grant. Likewise, the Sports Union was being pushed successfully towards concentrating resources where they were neediest and towards imposing fee for service for users who were not current students. The main issue for ANUSA clubs and societies seemed to be accounting standards. Not surprisingly they were often lax; not surprising because the office bearers were usually inexperienced undergraduate students. Participation in the GSF committee was a learning experience for that included listening to the point of view of a Liberal Party member of the University Council, Phillip Ruddock, who had concerns about any funds being directed to political activities. The student representatives were reluctant to provide any service that should have been funded by the university itself out of its own recurrent government grant. But occasionally they were willing to make a contribution.

It should be noted in the current context that, if services were the sole issue, university management could choose to fund and/or provide them itself. The government has no intention, however, of providing already overstretched universities with the funds to do this. No provision was indicated in the 20052006 Budget. And if universities were allowed to include a services component in the tuition fee charged to fee-paying students it would contradict the government's VSU intentions. Most importantly, even if many services were continued in this way, the self-governing collective character of student unionism would be lost.

In my capacity as GSF chair I appeared before a Senate inquiry into student unionism early in the Howard years as a member of an ANU delegation headed by the then Vice-Chancellor, Prof. Deane Terrell. The Senate committee was chaired by Liberal Party Senator John Tierney from NSW and included Liberal senators Eric Abetz (Tasmania) and Jeannie Ferris (South Australia). It was an intimidating experience because the delegation was put on trial. I learnt then how antagonistic some Coalition MPs were towards student leaders, how little respect they appeared to have for the Vice-Chancellor, and how strongly they were committed to voluntary student unionism.

I have experienced student politics myself as elected Treasurer of the Flinders University Students Representative Council in 1968-69. I also held leadership positions in student clubs as diverse as the Aquinas Society (Catholic students) and the Flinders University Football Club, as both an undergraduate and postgraduate student and as a junior member of the academic staff. At that time I 
valued the university facilities and thought that I received my fair share of them in return for my contribution. Paying my compulsory fee was just a matter of course.

\section{The Minister's Case}

The minister's case against the status quo contains a number of elements (Nelson, 2005). It begins with an appeal to the principle of freedom of association and makes the link with industrial relations reform by noting that in its first term of government, 1996-98, the Howard government extended freedom of association to employees in the workplace. Now it wishes to extend to students that freedom to join or not join a student union. He argues his case not only on the grounds of principle but also of practicality. Nelson argues that, unfairly in his view, students 'must pay for amenities, facilities and services that they do not use and in many cases do not want'.

The most appropriate basis on which to proceed, according to the minister, is that students should not be forced to join any student organisation and should only pay for those services they personally use; that is, the principle should be user pays. According to the minister, 'no student will be compelled to pay a fee to it [the provider] or any other entity for the provision of an amenity, facility or service that is not of an academic nature.' According to the principle of user pays, 'students will purchase or organise in support of the services they want' and not a single service more.

Any university that failed to abide by this legislation would be penalised by having their Commonwealth government grant reduced by a significant amount per student, perhaps $\$ 100.00$. There will be no way out for defiant universities.

The minister asserts that he recognises the value of student services to universities. In fact, he claims that they 'are an essential part of university life.' But he reckons, in flagrant disregard of the free rider principle, that they should thrive, as some clubs and organisations do in the general community, on the basis of 'mutual support for agreed objectives'. Whereas the free rider principle makes it much more likely that, given a choice, few students will pay a fee if they can avoid it. They will be prepared to ride on the backs of others.

The minister, as former President of the doctor's union, the Australian Medical Association, is of course not unaware of the problems faced by clubs and organisations in the general community. But he neglects to mention them on this occasion.

Nelson rejects any claim to special character or special needs for universities. He seems to have no sense of the university as a separate community. His speech is replete with references to bringing universities in line with community standards. For instance, he argues: 'The Government is extremely committed to

1 The minister's case was published in the The Australian, Higher Education Supplement, 23 March 2005. This informative supplement also contains articles on VSU from various perspectives by Prof Ian Chubb (ANU), Prof Millicent Poole (Edith Cowan University), Andrew Norton, Felix Eldridge (National Union of Students), and others. 
making sure that the choice in Australian universities is no less than that which applies in the rest of Australian society'.

This view of universities is consistent with the conservative economic philosophy which the Government is applying to policies across the board and across the country. This philosophy sees politics as driven by self-interest. It is the philosophy of the New Right that has steadily gained ground in Australian politics since the 1980s, undermining many traditional Australian institutions in the process (Kelly, 1990). There should be no exceptions in the government's view. If rural Australia, for instance, is not seen as having special needs then nor will university campuses wherever they are located.

The remainder of the minister's second reading speech is devoted to illustrating his argument by reference to special categories of students. These include disadvantaged single mothers or distance education students, who either have not the time or interest to take advantage of student services, cannot afford to pay for student services or cannot make use of the services because they study offcampus.

Interestingly, only by inference is there any mention of that other category of student, who is seeking very determinedly a change to the present arrangements. They are those students whose objection is to membership of student associations led by students of another political persuasion. Generally Liberal Party students do not have much support in campus elections, perhaps because voting is not compulsory but more likely because Labor generally claims the majority support of tertiary educated young people. Members of the Australian Liberal Students Federation (ASLF) have assisted the minister in the drafting of the bill. They are often motivated by personal experience of party politics on campus rather than abstract political philosophy. Their perception of CSU is framed in terms of special interests. According to ASLF president, Julian Barendse, CSU enables the Left 'to keep hold of the student cheque book. They have a vested interest to keep this situation where they can use this money for their own gains' (The Australian, 3 March 2005). The same motivation appears to be true of former student politicians among the ranks of government senators, such as Eric Abetz, who was a student leader at the University of Tasmania from 1976-1981 (Abetz, 2005)

The style of the government's argument bothers me because it refuses to give any credence to the most serious arguments for the status quo. The Minister for Education, Brendan Nelson, has been trivialising the issue. For the minister the case seems to be about whether sausage rolls on campus are more expensive than off campus; that is, whether private enterprise can provide cheaper goods and services than the public sector. He makes these points, in the cut and thrust of politics, to undercut the value of campus facilities to students and to break down the boundaries between campuses and the rest of the community.

The minister does not acknowledge, and is perhaps unaware, that many university services have already been privatised, in line with contemporary public service practice. While some student union services are directly provided to students by union employees, there are already numerous examples where these 
services are in direct competition with privately owned facilities on the university campus. Food outlets are a good example.

This takes no account of the differences between universities anyway. In my own experience, while the price of off-campus sausage rolls may be relevant to students at an inner-city university like ANU where students do have a legitimate alternative nearby, it is totally irrelevant to students isolated on an outer suburban campus like Flinders University or a regional out-of-town campus like the University of New England.

\section{Response to the Minister}

Nelson raises legitimate issues of a practical kind about equity, but only ones that apply to a minority of students. He is concerned that needy students should have to pay a fee. He is also concerned about individuals who are not making as much use as other students of the sporting, welfare and social facilities provided by student unions (or even any use at all). He is concerned about students who are rarely on campus because they are studying part time or studying on line.

None of these arguments are grounds for doing away with a compulsory fee for most students although they may be grounds for providing larger discounts, perhaps even exemptions, to certain categories of students. Another group is made up of students, like trainee teachers and nurses and social workers, who are required to do extensive practicums off campus. They are exceptions to the general rule. Policies should not be made on the basis of hard cases. Needy students still have to pay the Higher Education Contribution Scheme (HECS), of course, which is a far larger fee. But the minister is unconcerned about this burden on students. He emphasises the up-front nature of university service fees by comparison with the deferred nature of HECS

There is no doubt that some students get better value for money out of the compulsory fee than others do. They are not likely these days to be advocates of left-wing politics, but probably students whose special needs put an extra drain on resources, like extra counselling, or students who participate in a sport, like diving or rock-climbing, that needs expensive equipment. They may be just regular users of food services or campus bars. These students may or may not be needy.

But that is the case in many other community situations. In the largest community of all, the Australian democratic political system, some in the community get a better return from the tax system too because they make more frequent use than others of common facilities, like hospitals and schools. But try to argue a case for lower tax because you are a healthy childless person. You will probably be told that you are just the type of person who should pay more in order to support others with greater needs or responsibilities. The government's response is often a compulsory levy on everyone to lock you in to health insurance.

The same is true in the private sector too. Some students of private schools, for instance, get a better return from their parents' investment if they participate more frequently in using common facilities like sports ovals and music facilities. 
Try to argue you should pay less for your child because they have no interest in any communal activity. You will probably be told that your child should get more involved in the general school community. As a consequence they will get better value for their parents' dollar.

The key word is common facilities. We live in an increasingly individualist age. The idea of user pays is the minister's mantra. No wonder that a common fee is coming under threat. The minister has been chipping away at the peripheral weaknesses of CSU rather than seriously tackling head on the central issues, such as the balance of costs and benefits for the majority, and the enduring value of the university community.

\section{Student Voice and Student Services}

Before coming back to the issue of collective facilities versus individual choice I want to consider several further arguments against VSU. They can be summarised as the dangers to the student voice and to student services.

There will undoubtedly be some satisfaction in government circles if the organised voice of students is stifled. That voice is generally anti-government (though not just anti-Coalition governments). And student organisations can be training grounds for Labor politicians. An ANUSA anti-VSU poster argued: 'The aim of VSU is to remove the ability of students to organise against further attacks on education, such as upfront fees and course cuts'.

This interpretation should be taken seriously. No government enjoys funding its critics. There is persuasive evidence in research published by the Australia Institute, moreover, that the Howard government has sought systematically to silence critical NGOs through threatening them and often removing their government funding (Maddison, Dennis and Hamilton, 2004). Students have been to the forefront in opposing government policies towards asylum seekers and refugees. Nevertheless the power of the student voice should not be overestimated in the wider scheme of things. The government is faced with much more powerful critics.

Protection of student services is a stronger ground upon which to argue. That is the line taken in posters issued by the National Tertiary Education Union (NTEU, 2005), which argues:

Student organisations make a valuable contribution to university life, and provide important services like childcare and advocacy to students. Without student unions, many services students and staff depend upon will close, and student support and representation will disappear... .

Some special categories of students, such as international students, who lack ties with the wider local community and often live on campus, are particularly dependent on these services. And the numbers of such international students is rapidly increasing with government encouragement. 
University sporting facilities, including sporting fields, gymnasia and sporting teams, are also a ground on which to argue with the government. (Harris, 2005) These facilities contribute to student health and wellbeing. Team sports engender camaraderie and build friendships outside the classroom with fellow students. Furthermore university sports unions provide an undoubted platform for talented student sportsmen and sportswomen to make the jump into elite sport. But for most students the sports union offers a chance to be part of a community. It is the question of community to which I want to return.

\section{The University Community}

Traditionally the universities, reflecting their origins in monasteries, are referred to as communities. In particular, universities are communities of scholars. This is not the language of the government. Rather Nelson speaks of universities not as communities but as providers of 'academic services' of the narrowest kind. This language is pernicious and should be resisted within universities. Students are more than just clients. It divides what universities do into 'academic' and 'nonacademic' services.

Unfortunately, it must be admitted, that the traditional idea of the university is coming under threat not just from the minister. CSU works best and can most easily be justified in a situation where the university is a community in which students can make the most of campus life, including common facilities. In modern society there are many factors working against this idea.

The expense of going to university makes participation increasingly difficult for many students. One consequence is the related increase in part-time work that students must undertake just to exist. Such part-time work is creeping further into student life every year. If academic work is being threatened in such a way one can be sure of the even broader negative impact on campus life of this development.

My own observations and those of my colleagues is that the balance between paid work and study for the average full-time student is tipping more and more towards paid work. Full-time students who work 20 hours in paid work are common. I have heard of students who maintain a full university load even while working as much as 35 hours per week off-campus. The tyranny of the dictates of the demands of employers influences not just the number of hours that students can spend on campus but also the particular hours they can spend. This means that staff notice students more and more rushing from class to class and organising their enrolment around whatever classes can be fitted in between paid-work commitments.

The quality of student performance suffers under these circumstances. I have noticed that this phenomenon occurs even at fourth year Honours level in the Bachelor of Arts degree. The Honours year used to be sacrosanct. As a student you were expected to concentrate fully on your formal studies and on the informal life on campus with your fellow Honours students. More and more that is just not the case and students are trying to complete the Honours year under enormous 
pressure of paid work off campus. There is very little staff can do to ameliorate the consequences of this development.

A second factor is information technology. The increased use of such technology in university teaching is another factor. Nelson correctly notes the interests of 'fully online students who don't even set foot on campus'. Such students are only a small minority, but it is growing. More important are those on-campus students whose courses increasingly provide computer access to full course materials, such as lecture notes and supplementary reading materials. Students increasingly can pass courses without attending lectures in person. Universities often mandate such an approach to teaching and learning as best practice. They are effectively shooting themselves in the foot.

For all its undoubted benefits in providing flexibility, information technology is inevitably loosening the ties between students and that physical space called the university campus. The virtual library, replacing books on the shelves, is being followed by the virtual lecture theatre, replacing face-to-face contact with the lecturer. No one can blame students for making the most of this flexibility but there are costs to students that should be recognised. The university community becomes less real to them.

There are other aspects of life in a modern university that lessens the sense of community. Some of these apply to the place of academic staff in universities. Like other institutions in the public sector universities are now governed according to the new public administration. These means that decision-making is more hierarchical and less collegial. Office-holders like Deans are appointed rather than elected. Meetings of faculty members are occasions for dissemination of information from above than collegiality. Furthermore the amalgamation of departments in bigger administrative units, such as schools, is damaging those micro-communities built around professional disciplines.

\section{Conclusion}

The proposal to introduce VSU adds to these other threats to the university community. Students attend universities not just to receive academic services. They attend to soak up the university experience. This experience has often been called, as NTEU (2005) does, 'a well-rounded education':

University education has always been about more than classes, exams and research. Universities are communities of students and staff which create vibrant on-campus life. Sporting and social clubs, drama and cultural activities, venues for eating and meeting, political representation and student self-government are all important parts of the university experience.

The university community that is central to my belief in the virtues of CSU is under threat from a number of directions. I lament its passing. There is a sense of inevitability about it but nothing is inevitable in politics. 
For all these reasons the vigorous defence of CSU that is being waged is to be marvelled at. The ground is being cut from under the feet of the defenders not only by the direction that higher education is travelling, but also by the direction in which society as a whole is moving.

VSU might even be popular with the majority of students. After all it is being sold as cash in hand and the hip pocket nerve is a powerful motivator. In fact, cutting out the student fee is likely to be just as popular with the student body as are tax cuts rather than increased services seem to be with the general population at election time. Recent elections have shown this.

Nevertheless the defence of CSU is not just the sentimentality of traditionalists. Its defenders are fighting for a collective good that is precious. We will see what the impact of its removal will be from 2006 onwards. At the very least it poses a considerable risk to the quality of community life on campus.

While it is true that some of the services could be funded by other means, such as out of the general revenue of the universities, there is no replacing the spirit of the university community that would be lost.

\section{References}

Abetz, E. (2005), 'University students can decide on unionism themselves, The Canberra Times, 1 April.

Harris, G. (2005), 'Starve sport and you fatten Australia', The Australian (4 May):43.

Kelly, P. (1990), The End of Certainty, Allen and Unwin, St Leonards.

Maddison, S., R. Dennis and C. Hamilton (2004), 'Silencing Dissent: Non-government Organisations and Australian Democracy', The Australia Institute, Discussion Paper No. 65 , June.

Nelson, B. (Minister for Education) (2005), 'User-pays the Fairest Formula', The Australian Higher Education Supplement, 23 March.

NTEU (2005), National Bulletin, April. 